\title{
PE. CLÁUDIO PERANI: UM HOMEM QUE ULTRAPASSOU A ACADEMIA...
}

Eu conheci o Pe Cláudio Perani, SJ, já no final da década de sessenta, quando como estudante jesuíta visitei o CEAS - Centro de Estudos e Ação Social, em Salvador, Bahia. Eu era jovem (quase adolescente ainda) cheio de ganas para estudar sociologia. Tinha recém iniciado o meu Curso de Ciências Sociais. O Pe Cláudio se afigurava para mim como alguém imponente. Eu me sentia bastante tímido junto a ele, mas percebia também um grande carinho da parte dele. Suas palavras foram de encorajamento, mas também de alerta para não sucumbir na Academia.

Mesmo que eu não tivesse a maturidade suficiente, na época, para entender o alcance profundo de muito do que eu ouvia e via no ambiente do CEAS que estava iniciando, aquele contato foi marcante para mim. Voltei diversas vezes ao CEAS ao longo de minha vida depois, sobretudo na função que eu desempenhava na coordenação da Comissão do Apostolado Social. Em diversas reuniões, tive outras oportunidades de sentar com Pe Perani. O seu modo de ser aos poucos foi desfazendo em mim a figura imponente que me intimidava e deu lugar ao verdadeiro Pe Cláudio acolhedor, generoso, sempre atento para provocar o novo e estimular passos proféticos e corajosos. Era alguém que sabia o que queria e passou a aparecer para mim como uma espécie de vigia contra o fácil caminho de acomodação das estruturas institucionais.

Confesso que isto repercutiu muito no meu modo de ser na Academia. Toda a minha trajetória como jesuíta esteve ligada à atividade na Universidade do Vale do Rio dos Sinos, na área da sociologia. Dividi sempre, no entanto, esses quase cinquenta anos de Academia, com as atividades na área do apostolado social de Província. Aliás, continuo até hoje nesta lida dupla, sempre na busca de criar uma maior sinergia entre os dois horizontes.

Coloquei no título deste meu pequeno depoimento uma adjetivação do Pe Cláudio, que pode parecer uma provocação: "um homem que ultrapassou a Academia". De fato, é provocação, pois o Perani tinha muita reserva às fórmulas que vinham prontas do meio acadêmico ou dos acadêmicos. Ele parecia que não estava nem aí com a Academia. Por vezes, no entanto, se insurgia abertamente contra... O seu coração pulsava verdadeiramente ao ritmo do pensamento popular. Mostrava-se extremamente sensível com as ideias que 
brotavam no chão da prática popular. O termo "ação" parece ser o núcleo em torno do qual girava o seu pensar.

Para mim, o Perani, sem ser da Academia, sem querer dela participar, acabou ajudando a derrubar muros e transpor obstáculos para afirmar a verdadeira Academia. Ele foi um intelectual tremendamente transdisciplinar, sem nunca talvez ter efetivamente cultivado este conceito. Hoje, quando lemos depoimentos sobre ele e quando revisitamos os seus textos, isto aparece com toda clareza. Para ele a produção do conhecimento passava por beber na sabedoria popular, beber a seiva da ação concreta do dia a dia nas lutas e movimentos, em suma existem saberes que a Academia normalmente despreza ou cultiva à margem, que precisam ser levados a sério. É o que está no cerne do que vem sendo denominado de transdisciplinaridade. Costumo dizer que a transdisciplinaridade, que é esta prática de levar a sério saberes de fora das disciplinas, é a única tábua de salvação da própria Academia no mundo complexo de hoje. O Perani se coloca neste horizonte, nos inspirando para uma "universidade itinerante", "universidade em saída", para utilizar uma analogia do próprio Papa Francisco.

Na mesma linha de raciocínio, pode-se entender que o Perani, também, foi um homem que se adiantou ao que hoje está em vigor e sendo debatido, na Academia, como política da "curricularização da extensão". Talvez eu esteja sendo demasiadamente "herético" ao misturar o nome do Pe Cláudio Perani tão ousadamente com coisas da Academia. Ele certamente não concordaria. No entanto, eu entendo que se podemos imaginar um mundo acadêmico no qual o Pe Perani acreditaria, seria o de uma Academia comprometida com a busca de soluções concretas para a sociedade. Ou seja, currículos e práticas de ensino e de pesquisa efetivamente imbuídos de preocupação com o presente e o futuro da sociedade e a solução dos problemas concretos da humanidade do planeta terra. Uma Universidade que não mais simplesmente faz Extensões de sua prepotência conhecedora, mas Universidade em Extensão, onde a sua própria razão de ser é a produção do conhecimento e das inovações sociais e tecnológicas em diálogo permanente e fecundo com os atores concretos da sociedade, cultivando as melhores formas de superar as exclusões e as desigualdades.

O CEAS, um Centro Social vigoroso até hoje, no qual o Perani exerceu longamente o papel de líder na grande construção sempre coletiva, foi certamente um grande aprendizado para ele. Mesmo que se deva dizer que nele muitos também aprenderam dele. Com a longo 
aprendizado no CEAS, quando o P. Cláudio abraçou sua nova missão em terras amazônicas, não transpôs simplesmente a ideia daquele Centro para Manaus, mas protagonizou a organização do Serviço de Ação, Reflexão e Educação - SARES, que hoje, e seu novo formato, é o Serviço Amazônico de Ação, Reflexão e Ação Socioambiental. É muito expressivo e significativo que Perani tenha rejeitado a ideia de ser um Centro, para propor um Serviço. Não um Centro de Estudos, mas sim um Serviço de Ação. A reflexão (estudo) é decorrência. Faz parte da ação transformadora. Assim como é decorrência e faz parte da ação transformadora a educação.

Temos um Perani que em sua vida deu o salto do "conhecimento que ilumina a prática" para a "prática que gera o conhecimento". A lógica da própria produção do conhecimento se inverte. A lógica de quem deve protagonizar esta produção se inverte e toma novos rumos. A opção de Cláudio Perani é uma provocação para a inclusão dos sujeitos excluídos, para com a sua bagagem cultural e prática, ajudarem a transformar a Academia e toda a produção do conhecimento. Quando hoje participo das lutas de negros e indígenas no sentido de não verem simplesmente a sua temática incluída na Academia, mas de eles serem os verdadeiros protagonistas de sua temática neste mesmo meio acadêmico, muitas vezes se desenha com muita clareza, no meu horizonte, o perfil do P. Cláudio Perani.

Ele foi alguém que ultrapassou a Academia! Muito obrigado, P. Cláudio Perani! Que o seu nome continue a fortalecer as lutas de todas e todos!

Pe. José Ivo Follmann, SJ1

\footnotetext{
1 Professor e pesquisador no Programa de Pós-graduação em Ciências sociais; Diretor de Assistência Social das Mantenedoras; Secretário da Justiça Socioambiental.
} 